\title{
Allelopathic interactions between the macrophyte Egeria densa and plankton (alga, Scenedesmus acutus and cladocerans, Simocephalus spp.): a laboratory study
}

\author{
Cristian A. ESPINOSA-RODRÍGUEZ, ${ }^{1}$ Ligia RIVERA-DE LA PARRA, ${ }^{2}$ Aurora MARTÍNEZ-TÉLLEZ, ${ }^{1}$ \\ Gisela C. GÓMEZ-CABRAL, ${ }^{1}$ S.S.S. SARMA, ${ }^{3 *}$ Sarma NANDINI ${ }^{3}$
}

\begin{abstract}
${ }^{1}$ Postgraduate Programme in Marine Sciences and Limnology, National Autonomous University of Mexico, Ciudad Universitaria, Av. Universidad 3000, 04510 México City; ${ }^{2}$ Postgraduate Programme in Biological Sciences, National Autonomous University of Mexico, Postgraduate Studies Building, CU, Coyoacán, 04510 Mexico City; ${ }^{3}$ Laboratory of Aquatic Zoology, Division of Research and Postgraduate Studies, National Autonomous University of Mexico, Campus Iztacala, Av. de los barrios \# 1, Los Reyes Iztacala, 54090 Tlalnepantla, México

*Corresponding author: sarma@unam.mx
\end{abstract}

\begin{abstract}
Allelopathic interactions between macrophytes and zooplankton are important to understand the plankton dynamics in shallow waterbodies. Egeria densa is a native, perennial, submerged macrophyte in the tropical and subtropical zones of South America. It has been introduced to Central and North America and is now common in many Mexican lakes. This macrophyte produces chemical substances that negatively affect some phytoplankton species. However, it is not clear how zooplankton species adapt different life history strategies in the chemical presence of this macrophyte. Here, we tested the direct and indirect effects of allelochemicals released by E. densa on the population growth of Scenedesmus acutus and on the demographic variables of three species of Simocephalus, S. exspinosus, S. serrulatus and S. mixtus (via alga exposed to the macrophyte allelochemicals). To quantify the effect of E. densa on S. acutus we set up four treatments: control, artificial Egeria, natural Egeria and allelochemicals from Egeria. To test the allelochemical effects on Simocephalus species, we compared four treatments: Control, indirect effect (using S. acutus grown on Egeria-allelochemicals), direct effect (using Egeria-conditioned medium) and together with direct and indirect effects. Scenedesmus had the highest cell density in the presence of allelochemicals from Egeria, followed by controls. The specific algal growth rate $(\mu)$ between control and allelochemicals treatment was not significant $(P<0.05)$. However, the $\mu$ of alga in the presence of artificial or natural Egeria was significantly lower than in controls or in treatments involving allelochemicals. The age-specific survivorship of the three cladoceran species was longer in treatments containing Egeria-conditioned medium. Cladocerans receiving Egeria conditioned-medium and algae cultured on macrophyte-allelochemicals also had a longer survivorship. Daily fecundity of S. serrulatus increased after reaching mid-age while S. expinosus and S. mixtus showed continuous reproduction starting from the first week. In general, Egeria-allelochemicals enhanced the age-specific reproductive output for all the three cladoceran species. The average lifespan of the three Simocephalus varied from 17 to 46 days, depending on the cladoceran species and treatment. S. serrulatus had lower lifespan compared to other two cladoceran species. For the three species, lifespan significantly increased in treatments containing macrophyte-conditioned medium + algae grown on the plant-allelochemicals; also under these conditions, both gross and net reproductive rates were significantly enhanced. This stimulatory effect was also evident in generation time (about 50\% higher). The rate of population increase ranged from 0.23 to 0.38 per day for the three tested Simocephalus species but there were no significant differences $(P>0.05)$ among treatments. Our results suggest that the biological activity as well as physical structure of $\mathrm{E}$. densa had negative effects on $\mathrm{S}$. acutus population growth but had stimulatory effects on the demography of Simocephalus.
\end{abstract}

Key words: Allelopathy; life-table variables; zooplankton; allelochemicals; phytoplankton.

Received: March 2015. Accepted: November 2015.

\section{INTRODUCTION}

Many freshwater lakes around the world are small, shallow and display two strongly contrasting states (Scheffer et al., 1993): one dominated by macrophytes and low turbidity and the other dominated by phytoplankton and high turbidity (Scheffer, 2004). In shallow waterbodies there exists an antagonistic relationship between phytoplankton and macrophytes. In macrophytic zones, low water turbulence, reduced light intensity and low nutrient concentrations in water limit phytoplankton growth
(Lürling et al., 2006; Muylaert et al., 2010). However, macrophytes also affect plankton through the release of allelochemicals into the medium. Macrophytes belonging to the genera Elodea, Stratiotes, Chara and Myriophyllum release chemical substances that alter the abundance of phytoplankton (Körner and Nicklish, 2002; Gross, 2003; Hilt, 2006), and have effects on zooplankton behavior (Pennak, 1973; Meerhoff et al., 2006) and lifetable variables of cladocerans (Burks et al., 2000; Cerbin et al., 2007; Gutierrez and Paggi, 2014). Most studies concerning the allelopathic effects of macrophytes have been on 
phytoplankton in temperate systems, while such works from subtropical and tropical zones are limited (Meerhoff et al., 2006; Vanderstukken et al., 2011; Dong et al., 2013). In addition, the information available regarding the effect of chemical cues from macrophytes on many genera of cladocerans including Simocephalus that inhabit lake areas with aquatic vegetation is inadequate (Hilt, 2006).

The effect of chemical stress provoked by pesticides, heavy metals and chemical cues on cladocerans has been evaluated using different approaches such as somatic growth rate, population growth, feeding and filtration rates, diet selection, survivorship and life table changes (Lass and Spaak, 2003). In a review, Sarma and Nandini (2006) summarized some of the ecotoxicological studies on cladocerans using demographic variables. Since demographic changes are sensitive to different kinds of biotic and abiotic factors and are easily quantifiable, most workers have used the life table method to quantify the effects of chemicals on zooplankton (Conde-Porcuna, 1998; Doksaeter and Vijverberg, 2001; Nandini et al., 2004). Some stressful conditions such as low light intensity, herbivory, predation and high temperatures are determining components in the production and release of chemical cues, in this way the allelopathic effects of macrophytes on zooplankton vary considerably (Machacek, 1991; Gilbert, 2009; Gutierrez and Paggi, 2014). Here we tested the effect of $E$. densaconditioned medium on selected zooplankton species.

Egeria densa is a native, perennial, submerged macrophyte in parts of South America (Uruguay-ParaguayBrazil); it has been introduced, due to aquaculture, into several water bodies around the world (Lot and Novelo, 2004; Santos et al., 2011) and has thus become a nuisance in temperate, subtropical and tropical ecosystems because of its rapid growth (Duarte et al., 1999). Moreover, this submerged macrophyte produces allelopathic substances which affect phytoplankton adversely (Nakai et al., 1999; Mulderij et al., 2007; Vanderstukken et al., 2011). These allelochemicals also affect the demography of Daphnia in different ways (Cerbin et al., 2007).

Some studies have focused on effects of allelopathic substances produced by macrophytes on cladocerans, especially Daphnia, as the main bioassay organism which are typically limnetic. On the other hand, Simocephalus is usually found in the littoral/macrophyte zones where it could be affected in different ways due to its preference for the littoral regions. Thus, we selected three Simocephalus species of which $S$. serrulatus coexists with $E$. densa in nature.

We evaluated the effects of allelochemicals released by Egeria densa on the growth of Scenedesmus acutus and on the survivorship (average lifespan and age-specific survival) and on the demographic variables (age-specific fecundity, gross and net reproductive rates, generation time and rate of population increased $(r)$ per day) of three
Simocephalus species: S. exspinosus, S. serrulatus and $S$. mixtus exposed to macrophyte-allelochemicals, directly (conditioned-medium), indirectly (algal food exposed to allelochemicals), and both (direct and indirect effects). We supposed that the summarized effects of allelochemicals from Egeria densa would have stronger effects on life table variables of Simocephalus species than isolated effects (direct or indirect).

\section{METHODS}

\section{Plankton cultures}

We used three cladoceran species of the same genus Simocephalus: S. exspinosus, S. serrulatus and S. mixtus. These species were isolated from three different shallow water bodies from the State of Mexico (Mexico), because they rarely co-exist (Orlova-Bienkowskaja, 2001). The alga Scenedesmus acutus, was obtained from the University of Texas and Egeria densa and S. serrulatus were collected from Benito Juárez reservoir (Mexico City). S. acutus was batched-cultured in Bold's Basal medium (Borowitzka and Borowitzka, 1988) in 2L transparent glass bottles using continuous fluorescent light and aeration. The medium was supplemented with $3 \mathrm{mM} \mathrm{NaHCO}$ as a source of carbon. The algae were harvested after 8 days, centrifuged and resuspended in distilled water. The density of algae was estimated using a haemocytometer. All the cultures and experiments were maintained at a temperature of $22 \pm 1^{\circ} \mathrm{C}$.

Each of the three Simocephalus species was separately cultured for several months using moderately hard water, the EPA medium, and fed Scenedesmus acutus (about 0.5 $\times 10^{6}$ cells $\mathrm{mL}^{-1}$ ). EPA medium was prepared by adding $96 \mathrm{mg}$ of $\mathrm{NaHCO}_{3}, 60 \mathrm{mg}$ of $\mathrm{CaSO}_{4}, 60 \mathrm{mg}$ of $\mathrm{MgSO}_{4}$ and $4 \mathrm{mg}$ of $\mathrm{KCl}$ to $1 \mathrm{~L}$ of distilled water (Weber, 1993). The cladoceran cultures were transferred to fresh medium containing the specified concentration of fresh Scenedesmus from culture $\left(0.5 \times 10^{6}\right.$ cells $\left.\mathrm{mL}^{-1}\right)$ every second day by filtering the culture using a $100 \mu \mathrm{m}$ mesh. For obtaining the macrophyte-conditioned medium, Egeria was carefully washed using aged-tap water, then treated with ionized silver $(0.082 \%)$ for $40 \mathrm{~min}$. to minimize any interference from organisms that use this macrophyte as substrate, and finally rinsed a few times with distilled water. Thereafter, $750 \mathrm{~g}$ of wet $E$. densa was transferred to a transparent jar containing $9 \mathrm{~L}$ of EPA medium and placed under continued-diffuse light and constant mildaeration. After $24 \mathrm{~h}$, the conditioned-medium was collected by filtering it through a Whatman Polycap filter $(0.45 \mu \mathrm{m})$ (for obtaining allelochemicals liberated by the macrophyte without particulate organic matter).

\section{Effects of Egeria on Scenedesmus}

To test the effect of allelochemicals from the natural plant and its physical presence on the algal specific 
growth rate, we inoculated 16 (four treatments $\mathrm{X}$ four replicates for each treatment) transparent jars of $2 \mathrm{~L} \mathrm{ca-}$ pacity containing $1.6 \mathrm{~L}$ of Bold's Basal medium with $S$. acutus at an initial density of $0.125 \times 10^{6}$ cells $\mathrm{mL}^{-1}$. The treatment details are as follows:

Treatment 1: this comprised controls, with only Bold medium and Scenedesmus grown in this medium.

Treatment 2: we added plastic Egeria-like plants in biovolume similar to the live $E$. densa $\left(1.6 \mathrm{DW} \mathrm{g} \mathrm{L}^{-1}\right)$.

Treatment 3: received live $E$. densa.

Treatment 4: it consisted of Egeria-conditioned medium (in distilled water but supplemented with appropriate quantities of Bold's basal chemicals just before the start of the experiment). The biomass of Egeria used in the treatments corresponded to that we found in the field $\left(1.373 \pm 1.21 \mathrm{DW} \mathrm{g} \mathrm{L}^{-1}\right)$.

All the treatments received continuous fluorescent illumination (4300 lux 399 footcandle) and aeration. Following initiation of the algal growth experiment detailed previously, we daily quantified the density of Scenedesmus in the culture jars for 8 days, and later the algae were separately harvested. Algae harvested from the four treatments were used for further experiments with Simocephalus as mentioned below.

\section{Life table demography of Simocephalus spp.}

Four different treatments for each of the three species of Simocephalus were simultaneously setup. For each cladoceran species, the experimental design consisted of treatments 5-8.

Treatment 5: Controls (EPA medium $+S$. acutus cultured on Bold's medium (EPA+SceC), Treatment 6: EPA medium + S. acutus grown on macrophyte-allelochemicals $(\mathrm{EPA}+\mathrm{SceA})$, Treatment 7: conditioned- medium with allelochemicals $+S$. acutus grown on Bold's medium $(\mathrm{CM}+\mathrm{SceC})$; Treatment 8: conditioned medium with allelochemicals $+S$. acutus grown on macrophyte-allelochemicals $(\mathrm{CM}+\mathrm{Sce} A)$. Each treatment contained four replicates.

The life table demography experiments were conducted at one food level $\left(0.5 \times 10^{6}\right.$ cells $\mathrm{mL}^{-1}$ of $S$. acutus $=13 \mu \mathrm{g} \mathrm{DW} \mathrm{mL}{ }^{-1}$ per day (Mayeli et al., 2004). We used transparent jars of $100 \mathrm{~mL}$ capacity containing 50 $\mathrm{mL}$ test medium. Each jar received 10 neonates $(<24 \mathrm{~h}$ age) of one of the three species of Simocephalus. The cohorts were individually introduced into the test jars using Pasteur pipette under a stereoscopic microscope at 20x. Later, the test jars were placed on a horizontal shaker under continuous but diffused fluorescent illumination set at $22 \pm 1^{\circ} \mathrm{C}$. Following initiation of life table experiment, we daily quantified the number survived from the original cohort and the number of neonates produced, if any. Dead adults and neonates were removed and the surviving individuals of the original cohort were transferred to fresh jars of corresponding treatment. The survivorship and fecundity data of Simocephalus were used to calculate the following variables: i) average lifespan; ii) life expectancy; iii) gross reproductive rate, net reproductive rate; iv) generation time; and v) rate of population increase per day following Krebs (1985):

Life expectancy: $e_{x}=\frac{T_{x}}{n_{x}}$

Gross reproductive rate: $=\sum_{0}^{\infty} m_{x}$

Net reproductive rate: $R_{o}=\sum_{0}^{\infty} l_{x} \cdot m_{x}$

Generation time: $T=\frac{\sum l_{x} \cdot m_{x} \cdot x}{R_{o}}$

Rate of population increase, Euler-Lotka equation (solved iteratively)

$\sum_{x=w}^{n} e^{-r x} \cdot l_{x} \cdot m_{x}=1$

where, $T_{x}=$ number of individuals per day, $n_{x}=$ number of living individuals at the initiation, $l_{x}=$ the probability of an individual surviving to an age class $x, m_{x}=$ the age specific fecundity, $R_{o}=$ the average number of offspring per female, and $r=$ growth rate of the population.

\section{Statistical analysis}

Data from Scenedesmus acutus specific growth rate and the demography of zooplankton were statistically analyzed using analysis of variance (ANOVA) (Sokal and Rohlf, 2000) after satisfying the assumption of normality. Post-hoc (Tukey test) analysis was used for multiple comparisons utilizing the software Sigma Plot ver. 11.

\section{RESULTS}

Scenedesmus acutus grew better in the presence of allelochemicals in all the treatments, followed by the controls (Fig. 1). However, the growth rate of the alga was lowest in the treatment involving live Egeria. The maximum algal abundance $\left(22.3 \times 10^{6}\right.$ cells $\left.\mathrm{mL}^{-1}\right)$ was obtained in the presence of allelochemicals. Egeria in both natural and artificial forms reduced the algal specific growth rates $(\mu)$ compared with treatments with allelochemicals and controls (Fig. 2). Statistically, there were significant differences among the treatments $(\mathrm{P}<0.001$, one-way ANOVA).

The survivorship curves of the three Simocephalus spp. considerably differed depending on the treatment type and species (Fig. 3). The survivorship was longer in treatments containing macrophyte-conditioned medium (Treatments 7 and 8). In addition, the cladocerans in treatment $\mathrm{CM}+\mathrm{Sec} A$, i.e. conditioned-medium and algae cul- 
tured on macrophyte-allelochemicals, had also a longer survivorship. The neonates of $S$. exspinosus in controls $(\mathrm{EPA}+\mathrm{SecC})$ experienced some mortality during the first three weeks but thereafter, it was heavier. However, for S. mixtus the survivorship improved during the first two weeks in the treatment with allelochemicals from the macrophyte. Simocephalus serrulatus showed relatively little mortality during the first 10 days regardless of the treatment type. On the other hand, S. mixtus continued to die, albeit at a lower rate, starting from the first week in all treatments.

Data on the age-specific fecundity of the three tested cladoceran species are presented in Fig. 4. There were distinct patterns in the offspring production by the three species: regardless of treatment, S. serrulatus had higher rate of offspring production after reaching mid-age while S. exspinosus and S. mixtus showed continuous reproduction starting from first week. In general, macrophytes-allelochemicals treatment enhanced the age-specific reproductive output for all the three Simocephalus species compared to controls. However, the offspring production in the three Simocephalus species differed depending on the treatments. Only S. exspinosus, but not the other two species of Simocephalus, showed higher fecundity in treatments containing both $\mathrm{CM}+\mathrm{SceA}$ (direct+indirect effects) compared to that in $\mathrm{CM}+\mathrm{SceC}$ (direct effect).

Data on the selected life history variables of the three Simocephalus spp. subjected to different treatments are presented in Tab. 1. The average lifespan of the three cladocerans species ranged from 17 to 46 days depending

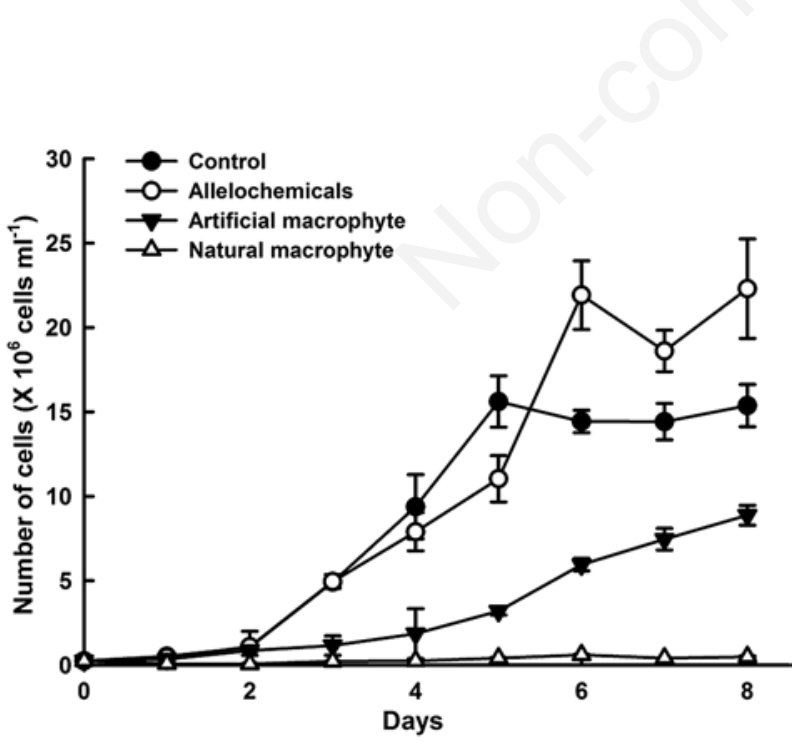

Fig. 1. Growth curves of the alga Scenedesmus acutus subjected to different treatments: with and without the allelochemicals and the presence or absence of the macrophyte Egeria densa. Shown are the mean values \pm SD based on four replicates. on the species and the treatment. Generally, S. serrulatus had a lower duration of life (17-24 d) than the other two Simocephalus spp. (range, 30-46 d). For the three species, lifespan, compared with controls, significantly increased in treatments containing macrophyte conditioned-medium with allelochemicals+algae grown on the plant-allelochemicals ( $\mathrm{P}<0.05$, F-test; two way ANOVA; Tab. 2). The rate of offspring production, both gross and net reproductive rates, was strikingly higher than in controls; the cladocerans on an average increased by about $350 \%$ for these parameters previously mentioned in treatment containing $\mathrm{CM}+\mathrm{Sce} \mathrm{A}$. This highly stimulatory effect was also evident in the generation time which was also enhanced by about $50 \%$. The rate of population increase $(0.23$ to 0.38 per day for all the species) was, however, not significantly $(\mathrm{P}>0.05)$ affected by the growth medium and the food source.

\section{DISCUSSION}

Egeria densa, in both natural and artificial forms, reduced the algal specific growth rates $(\mu)$ of Scenedesmus compared with controls or the treatments containing allelochemicals. The effect of the macrophyte on plankton is variable and in some cases phytoplankton growth is inhibited but in others stimulated (Erhard and Gross, 2006). On the other hand, Vanderstukken et al. (2011) have observed that the presence of Egeria densa has an adverse impact on the growth of Scenedesmus. Van Donk and van de Bund (2002) have also reported a significant reduction in the abundance of Scenedesmus acutus grown in the

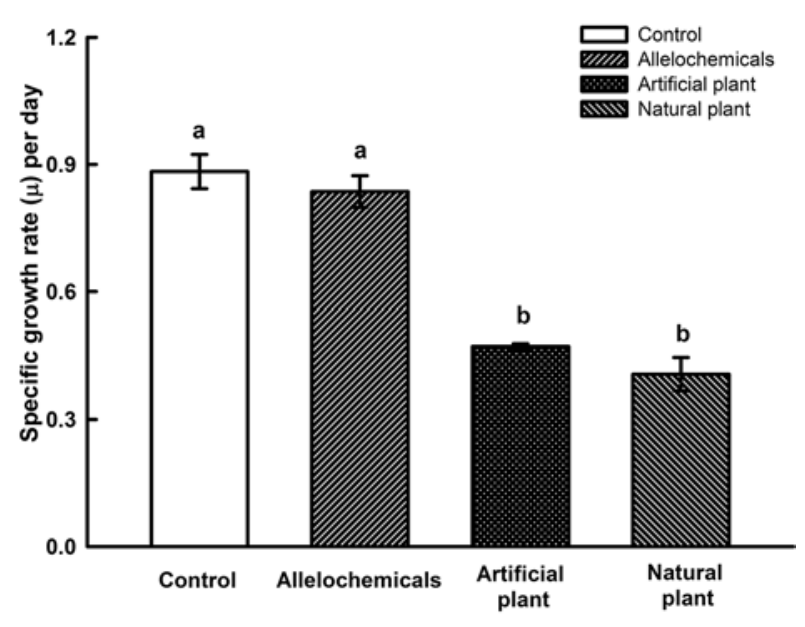

Fig. 2. Specific growth rate of the alga (Scenedesmus acutus) subjected to different treatments: with and without the allelochemicals and the presence or absence of the macrophyte Egeria densa. Shown are the mean values \pm SD based on four replicates. Data bars carrying similar alphabet are not statistically significant $(\mathrm{P}>0.05$, Tukey test). 
presence of Chara aspera under laboratory conditions. The macrophytes affect algae through physical interference in capturing light, compete for nutrients in the medium and produce allelopathic substances (Gross, 2003). In order to assess the effect of Egeria densa on Scenedesmus acutus, we conducted the Scenedesmus growth experiments under optimal conditions of light, temperature and nutrients and using a defined medium so that the differences found among the treatments could reflect the impact of macrophytes or macrophyte-derived allelochemicals. Thus, the differences in the specific growth rates $(\mu)$ of $S$. acutus in treatments containing the macrophytes (both natural and artificial) were evidently lower due to the physical structure that limited the algal growth as also observed by Lurling et al. (2006). Scenedesmus grown together with natural Egeria showed the lowest specific growth rate $(0.40)$ compared with controls $(0.83)$. This is because the live macrophyte caused both, physical interference in light availability, allelo- pathic influence and possibly physiological nutrient limitation to the alga.

In natural waterbodies macrophytes also inhibit phytoplankton growth by diminishing turbulence in water column, which increases the rate of algal sedimentation (Scheffer, 2004; Vanderstukken et al., 2014). We solved this problem by continuous aeration in all treatments. Macrophytes also decrease light availability by shading the phytoplankton (Mulderij et al., 2007; Hilt and Gross, 2008) which was observed in both the treatments containing natural and artificial plants compared with controls, i.e. treatment with no plants. Though the jars with algal cultures were continuously aerated, the shading by the macrophytes further decreased light availability and hence algal growth was reduced. Nutrient limitation of phytoplankton due to competition with macrophytes is still another possibility (we did not measure the nutrient levels in the test jars periodically), but provided adequate nutrient levels in the medium $\left(0.37\right.$ g. $\mathrm{L}^{-1}$ of $\mathrm{NaNO}_{3}, 0.11$ g.L
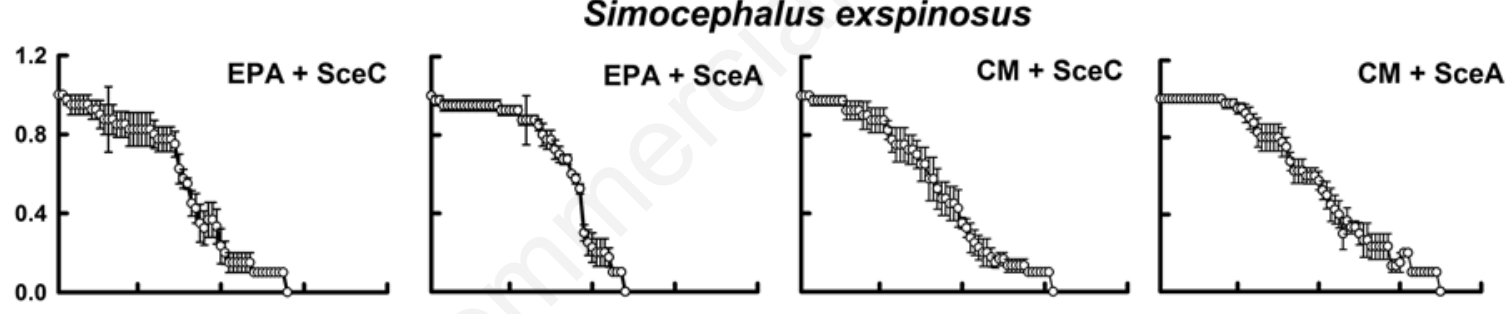

Simocephalus serrulatus
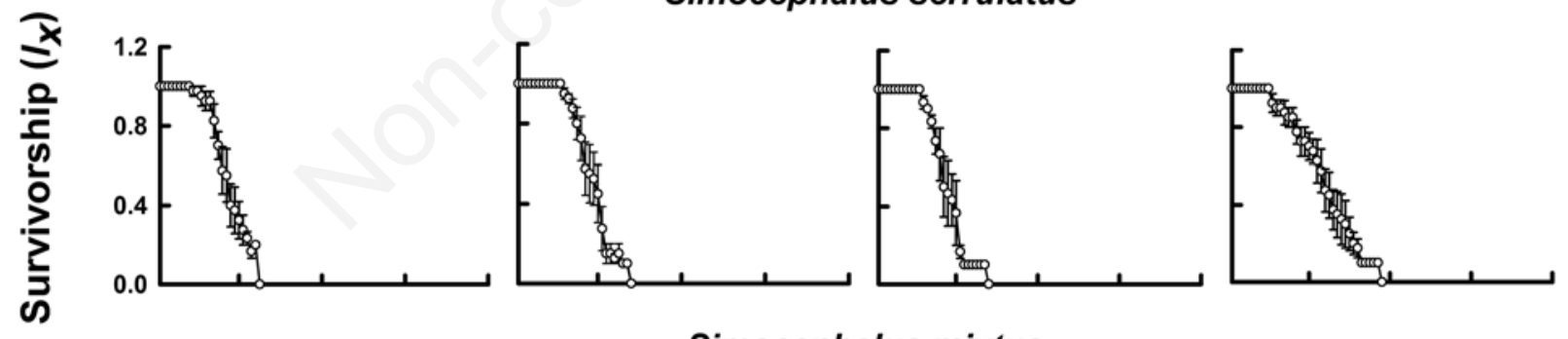

\section{Simocephalus mixtus}
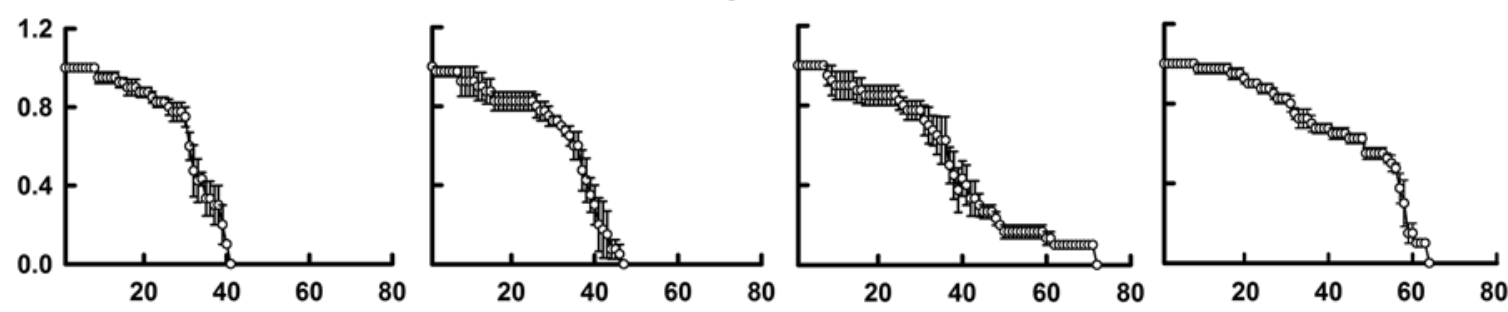

Age (days)

Fig. 3. Age-specific survivorship $\left(l_{x}\right)$ curves of $S$. exspinosus, $S$. serrulatus and $S$. mixtus cultured in relation to different treatments: $\mathrm{EPA}+\mathrm{SceC}(\mathrm{EPA}$ medium $+S$. acutus cultured on Bold's medium), EPA+SceA (EPA medium $+S$. acutus grown on macrophyte-allelochemicals), $\mathrm{CM}+\mathrm{SceC}$ (conditioned- medium $+S$. acutus grown on Bold's medium) and $\mathrm{CM}+\mathrm{Sce}$ A (conditioned medium $+S$. acutus grown on macrophyte allelochemicals). Shown are mean \pm SD based on four replicates (cohorts). 
${ }^{1}$ of $\mathrm{K}_{2} \mathrm{HPO}_{4}$ and $0.262 \mathrm{~g}$. $\mathrm{L}^{-1}$ of $\mathrm{KH}_{2} \mathrm{PO}_{4}$ ) to prevent nutrient limitation, if any. Allelopathic effects of macrophytes may also operate simultaneously with their other adverse effects from macrophytes, e.g. increasing light limitation for algae, in the algal culture systems (Gopal and Goel, 1993; Vanderstukken et al., 2011). Conditionedmedium enhanced phytoplankton growth leading to Scenedesmus to reach densities maxima. Our observations support Erhard and Gross (2006) who have demonstrated that allelochemicals from Elodea have inhibitory effects on some phytoplankton species but stimulated Scenedesmus growth. Our observations show that the highest specific growth of Scenedesmus was recorded in cultures exposed to Egeria-conditioned medium but without the physical presence of the macrophytes.

Zooplankton species also show variable responses to the presence of macrophytes (Dawidowicz and Ozimek, 2013; Gutierrez and Paggi, 2014). In general, studies concerning allelopathic effects of macrophytes on zooplankton are relatively few compared with macrophyte-phytoplank- ton interactions (van Donk and van de Bund, 2002). Our results showed that the allelochemicals indirectly (through Scenedesmus grown on Egeria-conditioned-medium) and directly (through the medium with allelochemicals in the test jars), affected the life history variables of Simocephalus spp., and the impact was high through both these routes. Age-specific survivorship curves reveal the pattern of mortality of a cohort population as they age. In laboratory populations, survivorship curves are usually rectangular where Simocephalus population experiences little mortality during the early stages and thereafter experiences heavy mortality due to physiological senescence (Krebs, 1985). This typical trend was evident only for $S$. exspinosus and $S$. mixtus. However, for S. serrulatus, after two weeks, the population began to experience heavy mortality in all treatments. These suggest that though the three cladoceran species belong to the same genus, they differ in their optimal conditions. Species of Simocephalus in general have long lifespan (30-70 days: Malhotra and Langer, 1991), a fact we also observed (average lifespan up to 45 days).

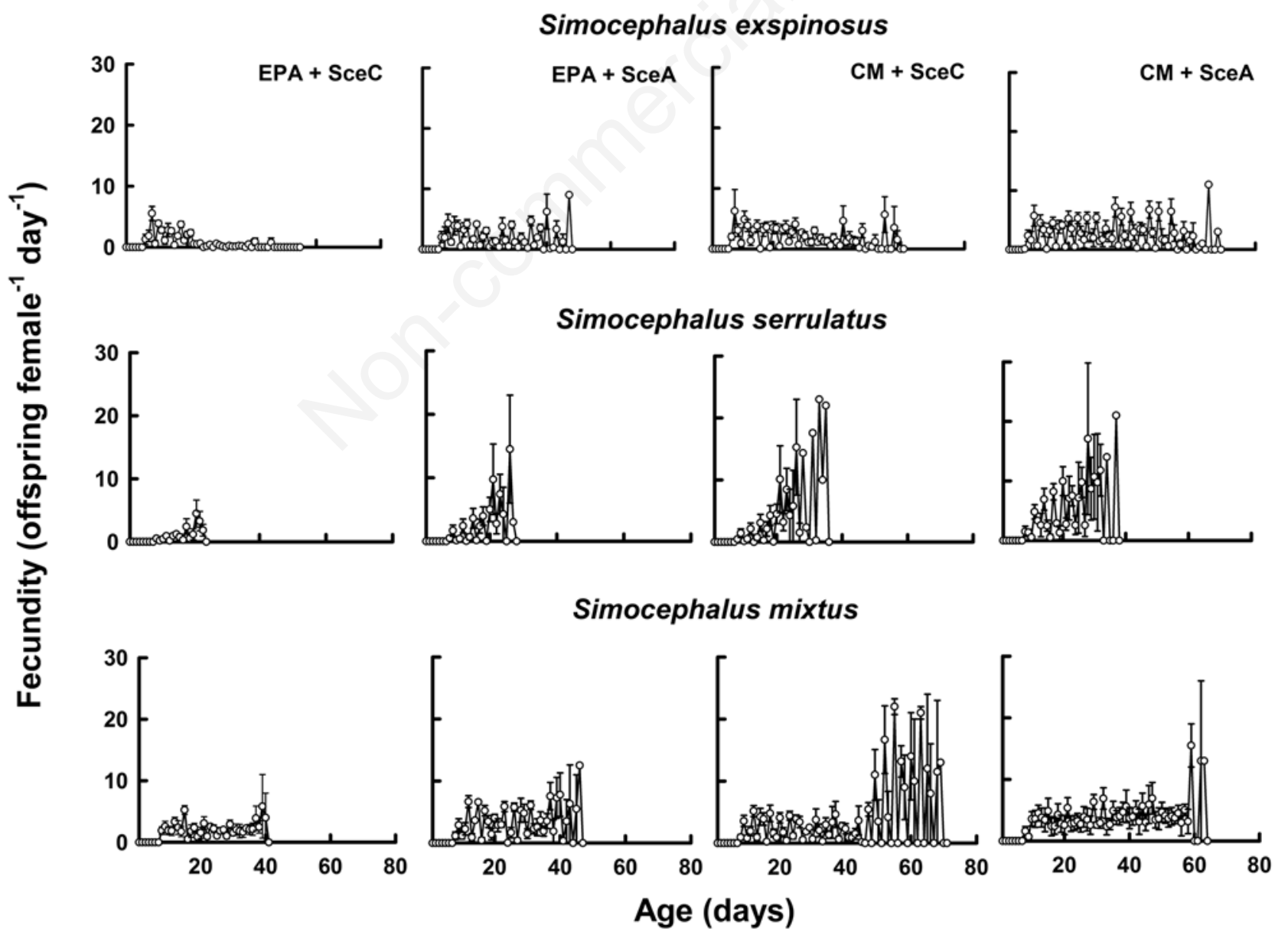

Fig. 4. Age-specific fecundity $\left(m_{x}\right)$ curves of $S$. exspinosus, S. serrulatus and S. mixtus cultured in relation to different treatments. 
Age-specific reproductive output of cladocerans varies depending on the species and the test conditions (Sarma et al., 2005). Since Simocephalus begins to increase their body size even after achieving age at first reproduction, the number of neonates developing in the brood chamber increases with age (Dumont and Negrea, 2002). This results in higher offspring production during the mid-reproductive age and thereafter it decreases due to physiological aging of the reproducing individuals (Dodson and Frey, 2001). This typical offspring production is also evident in this work on S. serrulatus and S. mixtus. However, this pattern varied in $S$. exspinosus suggesting that offspring production in this species is more or less continuous with similar number of neonates per clutch over a period of time as was also observed in $S$. vetulus by Fernández et al. (2014).

Studies on temperate pelagic cladocerans such as Daphnia cucullata and Daphnia longispina indicate that these taxa show horizontal migration towards macrophytes (Potamogeton lucens, Elodea canadensis, Equisetum fluviatile, etc.) during the day to evade fish-predation (Wojtal et al., 2003; Iglesias et al., 2007). Allelochemicals from Elodea, Nitella and Myriophyllum have been reported to repel some cladoceran species including Daphina or reduce their reproductive output (Pennak, 1973; Burks et al., 2000). However, in our study we observed the presence of Egeria allelochemicals enhanced the duration of lifespan and generation time of Simocephalus spp. as well as ele- vated their gross and net reproductive rates. This stimulatory effect of allelochemicals on zooplankton may be explained by hormesis (Duke, 2011). It seemed that hormesis occurs at relatively low stress levels as a measure of overcompensation through enhanced reproductive output (Gama-Flores et al., 2007). Some heavy metals and various chemical substances, including pesticides and plant allelochemicals, enhance the offspring production in zooplankton by elevating the reproductive rates (Calabrese, 2004). It is interesting to note that a great diversity of periphytic zooplankton including rotifers and cladocerans specialize in living in macrophyte-dominated environments indicates that an adverse allelopathic effect does not per se occur (Burks et al., 2000). In this context the suggestion of Burns and Dodds (1999) that the allelopathic interactions between macrophytes and zooplankton be studied more thoroughly is relevant, especially for periphytic species in tropical and sub-tropical environments.

\section{CONCLUSIONS}

The inhibition of the abundance and specific growth rates $(\mu)$ of Scenedesmus acutus by Egeria densa was due to its physical structure as well as its biological activity while the presence of its allelochemicals resulted in slightly higher algal densities. E. densa had a significant effect directly by enhancing survivorship as well as raising the age-specific reproductive output for the all three

Tab. 1. Selected life history variables of the three species of Simocephalus cultured under different test conditions: EPA+SceC (EPA medium $+S$. acutus cultured on Bold's medium), EPA+SceA (EPA medium $+S$. acutus grown on macrophyte-allelochemicals), $\mathrm{CM}+\mathrm{SceC}$ (conditioned- medium $+S$. acutus grown on Bold's medium) and CM+SceA (conditioned medium $+S$. acutus grown on macrophyte allelochemicals). For each cladoceran species, data carrying similar alphabet are not significant ( $\mathrm{P}>0.05$, Tukey test).

\begin{tabular}{|c|c|c|c|c|}
\hline \multirow[t]{2}{*}{ Treatments } & \multicolumn{4}{|c|}{ Species / life history variable } \\
\hline & & S. exspinosus & S. serrulatus & S. mixtus \\
\hline $\mathrm{EPA}+\mathrm{SceC}$ & \multirow[t]{4}{*}{ Average lifespan (days) } & $30.25 \pm 0.72^{\mathrm{a}}$ & $17.10 \pm 0.93^{\mathrm{a}}$ & $30.05 \pm 0.54^{\mathrm{a}}$ \\
\hline $\mathrm{EPA}+\mathrm{SceA}$ & & $33.67 \pm 1.11^{\mathrm{b}}$ & $18.20 \pm 0.97^{\mathrm{a}}$ & $32.4 \pm 1.71^{\mathrm{ab}}$ \\
\hline $\mathrm{CM}+\mathrm{SceC}$ & & $34.25 \pm 1.91^{\mathrm{abc}}$ & $23.65 \pm 3.04^{\mathrm{a}}$ & $36.12 \pm 2.86^{\mathrm{ab}}$ \\
\hline $\mathrm{CM}+\mathrm{SceA}$ & & $40.22 \pm 1.93^{\mathrm{c}}$ & $23.15 \pm 1.54^{\mathrm{a}}$ & $45.57 \pm 0.72^{\mathrm{b}}$ \\
\hline $\mathrm{EPA}+\mathrm{SceC}$ & \multirow[t]{4}{*}{ Gross reproductive rate (offspring female ${ }^{-1}$ ) } & $39.32 \pm 1.99^{a}$ & $17.05 \pm 1.93^{\mathrm{a}}$ & $67.22 \pm 4.65^{\mathrm{a}}$ \\
\hline $\mathrm{EPA}+\mathrm{SceA}$ & & $79.70 \pm 5.75^{\mathrm{b}}$ & $48.05 \pm 6.24^{\mathrm{ab}}$ & $126.53 \pm 4.31^{\mathrm{ab}}$ \\
\hline $\mathrm{CM}+\mathrm{SceC}$ & & $100.21 \pm 3.85^{\mathrm{bc}}$ & $129.15 \pm 39.56^{\mathrm{b}}$ & $193.83 \pm 42.10^{b}$ \\
\hline $\mathrm{CM}+\mathrm{Sce} \mathrm{A}$ & & $145.78 \pm 12.17^{\mathrm{d}}$ & $108.83 \pm 13.74^{\mathrm{ab}}$ & $211.17 \pm 11.35^{b}$ \\
\hline $\mathrm{EPA}+\mathrm{SceC}$ & \multirow[t]{4}{*}{ Net reproductive rate (offspring female ${ }^{-1}$ ) (survival-weighted) } & $32.62 \pm 2.07^{\mathrm{a}}$ & $7.95 \pm 1.94^{\mathrm{a}}$ & $47.97 \pm 0.85^{\mathrm{a}}$ \\
\hline $\mathrm{EPA}+\mathrm{SceA}$ & & $56.5 \pm 1.76^{\mathrm{b}}$ & $19.10 \pm 6.86^{\mathrm{ab}}$ & $83.2 \pm 5.21^{\mathrm{b}}$ \\
\hline $\mathrm{CM}+\mathrm{SceC}$ & & $66.50 \pm 3.91^{\mathrm{bc}}$ & $49.17 \pm 19.81^{b}$ & $77.1 \pm 8.98^{\mathrm{bc}}$ \\
\hline $\mathrm{CM}+\mathrm{SceA}$ & & $99.07 \pm 6.01^{\mathrm{d}}$ & $58.45 \pm 8.94^{\mathrm{ab}}$ & $144.45 \pm 2.53^{\mathrm{d}}$ \\
\hline $\mathrm{EPA}+\mathrm{SceC}$ & \multirow[t]{4}{*}{ Generation time (days) } & $13.97 \pm 0.66^{\mathrm{a}}$ & $15.14 \pm 0.23^{\mathrm{a}}$ & $19.04 \pm 0.74^{\mathrm{a}}$ \\
\hline $\mathrm{EPA}+\mathrm{SceA}$ & & $19.17 \pm 0.41^{\mathrm{b}}$ & $16.58 \pm 0.23^{\mathrm{a}}$ & $22.87 \pm 0.48^{\mathrm{ab}}$ \\
\hline $\mathrm{CM}+\mathrm{SceC}$ & & $19.53 \pm 0.51^{\mathrm{bc}}$ & $20.37 \pm 0.23^{\mathrm{b}}$ & $27.91 \pm 2.85^{\mathrm{ab}}$ \\
\hline $\mathrm{CM}+\mathrm{SceA}$ & & $24.77 \pm 1.53^{\mathrm{d}}$ & $17.73 \pm 0.29^{\mathrm{a}}$ & $30.78 \pm 0.24^{\mathrm{b}}$ \\
\hline $\mathrm{EPA}+\mathrm{SceC}$ & \multirow[t]{4}{*}{ Rate of population increase $(r)$ day $^{-1}$} & $0.33 \pm 0.01^{\mathrm{a}}$ & $0.28 \pm 0.06^{\mathrm{a}}$ & $0.29 \pm 0.003^{\mathrm{a}}$ \\
\hline $\mathrm{EPA}+\mathrm{SceA}$ & & $0.34 \pm 0.01^{\mathrm{a}}$ & $0.23 \pm 0.07^{\mathrm{a}}$ & $0.30 \pm 0.01^{\mathrm{a}}$ \\
\hline $\mathrm{CM}+\mathrm{SceC}$ & & $0.38 \pm 0.01^{\mathrm{a}}$ & $0.23 \pm 0.06^{\mathrm{a}}$ & $0.29 \pm 0.01^{\mathrm{a}}$ \\
\hline $\mathrm{CM}+\mathrm{Sce} \mathrm{A}$ & & $0.36 \pm 0.01^{\mathrm{a}}$ & $0.29 \pm 0.04^{\mathrm{a}}$ & $0.31 \pm 0.01^{\mathrm{a}}$ \\
\hline
\end{tabular}


Tab. 2. Results of the two-way analysis of variance conducted on the average lifespan, gross reproductive rate, net reproductive rate, generation time and rate of population increased of Simocephalus exspinosus, S. serrulatus and S. mixtus under direct (allelochemicals from the plant) and indirect (effect through the alga) effects of Egeria densa.

\begin{tabular}{|c|c|c|c|c|}
\hline Source of variation & df & Sum of square & Mean square & F-ratio \\
\hline \multicolumn{5}{|l|}{ Average lifespan } \\
\hline \multicolumn{5}{|l|}{ S. exspinosus } \\
\hline Direct (A) & 1 & 111.3 & 111.3 & $12.07 * *$ \\
\hline Indirect $(\mathrm{B})$ & 1 & 88.36 & 88.36 & $9.58^{* *}$ \\
\hline Interaction of A X B & 1 & 6.5 & 6.5 & $0.7 \mathrm{~ns}$ \\
\hline Error & 12 & 110.57 & 9.21 & \\
\hline \multicolumn{5}{|l|}{ S. serrulatus } \\
\hline Direct (A) & 1 & 132.25 & 132.25 & $9.8^{* *}$ \\
\hline Indirect (B) & 1 & 0.36 & 0.36 & $0.02 \mathrm{~ns}$ \\
\hline Interaction of A X B & 1 & 2.56 & $2 . .56$ & $0.19 \mathrm{~ns}$ \\
\hline Error & 12 & 161.8 & 13.48 & \\
\hline \multicolumn{5}{|l|}{ S. mixtus } \\
\hline Direct (A) & 1 & 370.56 & 370.56 & $30.0 * * *$ \\
\hline Indirect (B) & 1 & 139.24 & 139.24 & $11.61^{* *}$ \\
\hline Interaction of $\mathrm{A} \mathrm{X} \mathrm{B}$ & 1 & 50.41 & 50.41 & $4.2 \mathrm{~ns}$ \\
\hline Error & 12 & 143.86 & 11.98 & \\
\hline \multicolumn{5}{|l|}{ Gross reproductive rate } \\
\hline \multicolumn{5}{|l|}{ S. exspinosus } \\
\hline Direct (A) & 1 & 16121.59 & 16121.59 & $80.56^{* * *}$ \\
\hline Indirect (B) & 1 & 7387.13 & 7387.13 & $36.91 * * *$ \\
\hline Interaction of A X B & 1 & 26.87 & 26.87 & $0.71 \mathrm{~ns}$ \\
\hline Error & 12 & 2401.43 & 200.11 & \\
\hline \multicolumn{5}{|l|}{ S. serrulatus } \\
\hline Direct (A) & 1 & 44186.96 & 44186.96 & $155.82 * * *$ \\
\hline Indirect (B) & 1 & 710.11 & 710.11 & $2.5 \mathrm{~ns}$ \\
\hline Interaction of $\mathrm{A} \mathrm{X} \mathrm{B}$ & 1 & 7858.4 & 7858.4 & $27.71 * * *$ \\
\hline Error & 12 & 3402.86 & 283.57 & \\
\hline \multicolumn{5}{|l|}{ S. mixtus } \\
\hline Direct (A) & 1 & 44625.89 & 44625.89 & $22.98 * * *$ \\
\hline Indirect $(\mathrm{B})$ & 1 & 5875.61 & 5875.61 & $3.02 \mathrm{~ns}$ \\
\hline Interaction of $\mathrm{A} \mathrm{X} \mathrm{B}$ & 1 & 1761.48 & 1761.48 & $0.9 \mathrm{~ns}$ \\
\hline Error & 12 & 23300.78 & 1941.73 & \\
\hline \multicolumn{5}{|l|}{ Net reproductive rate } \\
\hline \multicolumn{5}{|l|}{ S. exspinosus } \\
\hline Direct (A) & 1 & 5844.6 & 5844.6 & $99.28 * * *$ \\
\hline Indirect (B) & 1 & 3186.6 & 3186.6 & $54.13 * * *$ \\
\hline Interaction of $\mathrm{AX} \mathrm{B}$ & 1 & 75.69 & 75.69 & $0.27 \mathrm{~ns}$ \\
\hline Error & 12 & 706.39 & 58.86 & \\
\hline \multicolumn{5}{|l|}{ S. serrulatus } \\
\hline Direct (A) & 1 & 6492.33 & 6492.33 & $12.4 * *$ \\
\hline Indirect (B) & 1 & 417.18 & 417.18 & $0.79 \mathrm{~ns}$ \\
\hline Interaction of $\mathrm{A} \mathrm{X} \mathrm{B}$ & 1 & 3.51 & 3.51 & 0.006 \\
\hline Error & 12 & 6280.78 & 523.39 & \\
\hline \multicolumn{5}{|l|}{ S. mixtus } \\
\hline Direct (A) & 1 & 8167.64 & 8167.64 & $70.97 * * *$ \\
\hline Indirect (B) & 1 & 10521.63 & 10521.63 & $91.42 * * *$ \\
\hline Interaction of $\mathrm{A} \mathrm{X} \mathrm{B}$ & 1 & 1032.01 & 1032.01 & $8.96^{*}$ \\
\hline Error & 12 & 1381.01 & 115.08 & \\
\hline \multicolumn{5}{|l|}{ Generation time } \\
\hline \multicolumn{5}{|l|}{ S. exspinosus } \\
\hline Direct (A) & 1 & 124.44 & 124.44 & $38.63 * * *$ \\
\hline Indirect (B) & 1 & 108.95 & 108.95 & $33.83 * * *$ \\
\hline Interaction of $\mathrm{A} \mathrm{X} \mathrm{B}$ & 1 & 0.001 & 0.001 & $0.0005 \mathrm{~ns}$ \\
\hline Error & 12 & 38.64 & 3.22 & \\
\hline S. serrulatus & & & & \\
\hline Direct (A) & 1 & 75.6 & 75.6 & $38.77 * * *$ \\
\hline Indirect $(\mathrm{B})$ & 1 & 12.36 & 12.36 & $6.34 *$ \\
\hline Interaction of $\mathrm{A} \mathrm{X} \mathrm{B}$ & 1 & 40.96 & 40.96 & $21.007 * * *$ \\
\hline Error & 12 & 23.4 & 1.95 & \\
\hline S. mixtus & & & & \\
\hline Direct (A) & 1 & 281.47 & 281.47 & $31.3 * * *$ \\
\hline Indirect (B) & 1 & 44.76 & 44.76 & $4.97 *$ \\
\hline Interaction of $\mathrm{A} \mathrm{X} \mathrm{B}$ & 1 & 0.9 & 0.9 & $0.1 \mathrm{~ns}$ \\
\hline Error & 12 & 107.89 & 8.99 & \\
\hline
\end{tabular}


Table 2. Continued from previous page.

\begin{tabular}{|c|c|c|c|c|}
\hline Source of variation & df & Sum of square & Mean square & F-ratio \\
\hline \multicolumn{5}{|c|}{ Rate of population increase } \\
\hline $\begin{array}{l}\text { S. exspinosus } \\
\text { Direct (A) } \\
\text { Indirect (B) } \\
\text { Interaction of A X B } \\
\text { Error }\end{array}$ & $\begin{array}{c}1 \\
1 \\
1 \\
12\end{array}$ & $\begin{array}{l}0.004 \\
0.000005 \\
0.001 \\
0.009\end{array}$ & $\begin{array}{l}0.004 \\
0.000005 \\
0.001 \\
0.0007\end{array}$ & $\begin{array}{l}5.51 * \\
0.007 \mathrm{~ns} \\
1.44 \mathrm{~ns}\end{array}$ \\
\hline $\begin{array}{l}\text { S. serrulatus } \\
\text { Direct (A) } \\
\text { Indirect (B) } \\
\text { Interaction of A X B } \\
\text { Error }\end{array}$ & $\begin{array}{c}1 \\
1 \\
1 \\
12\end{array}$ & $\begin{array}{l}0.002 \\
0.004 \\
0.004 \\
0.058\end{array}$ & $\begin{array}{l}0.002 \\
0.004 \\
0.004 \\
0.004\end{array}$ & $\begin{array}{l}0.59 \mathrm{~ns} \\
0.89 \mathrm{~ns} \\
0.94 \mathrm{~ns}\end{array}$ \\
\hline $\begin{array}{l}\text { S. mixtus } \\
\text { Direct (A) } \\
\text { Indirect (B) } \\
\text { Interaction of A X B } \\
\text { Error }\end{array}$ & $\begin{array}{c}1 \\
1 \\
1 \\
12\end{array}$ & $\begin{array}{l}0.00005 \\
0.0006 \\
0.0003 \\
0.003\end{array}$ & $\begin{array}{l}0.00005 \\
0.0006 \\
0.0003 \\
0.0002\end{array}$ & $\begin{array}{l}0.18 \mathrm{~ns} \\
2.29 \mathrm{~ns} \\
1.25 \mathrm{~ns}\end{array}$ \\
\hline
\end{tabular}

$d$, degrees of freedom; $n$, not significant; $* P>0.05 ; * * P<0.01 ; * * * P<0.001$.

Simocephalus spp. This implies the existence of allelopathic interactions between E. densa and Simocephalus. It is, however, necessary to analyze the allelopathy between macrophytes and zooplankton under natural conditions (e.g., through mesocosms) which are more complex than the somewhat simplified laboratory tests. We suggest that future studies on Egeria interactions with zooplankton need to focus on other zooplankton groups including rotifers and copepods in order to understand the effect of allelochemicals from macrophytes on zooplankton.

\section{ACKNOWLEDGMENTS}

We thank three anonymous reviewers for improving our presentation. This work was funded by PAPIIT- IN213513 and IA203315. CAER thanks CONACyT (CVU 257869) and the Postgraduate Programme in Marine Sciences and Limnology (PCML) for a doctoral scholarship.

\section{REFERENCES}

Burns CW, Dodds A, 1999. Food limitation, predation and allelopathy in a population of Daphnia carinata. Hydrobiologia 400:41-53.

Burks RL, Jeppesen E, Lodge DM, 2000. Macrophyte and fish chemicals suppress Daphnia growth and alter life-history traits. Oikos 88:139-147.

Borowitzka MA, Borowitzka LJ, 1988. Micro-algal biotechnology. Cambridge University Press, London: 477 pp.

Calabrese EJ, 2004. Hormesis: a revolution in toxicology, risk assessment and medicine. EMBO Rep 5:S37-S40.

Cerbin S, van Donk E, Gulati R, 2007. The influence of Myriophyllum verticillatum and artificial plants on some life history parameters of Daphnia magna. Aquat. Ecol. 41:263-271.

Conde-Porcuna JM, 1998. Chemical interference by Daphnia on Keratella: a life table experiment. J. Plankton Res. 20:1637-1644.

Dawidowicz P, Ozimek T, 2013. Cladoceran Moina branchiata cannot reduce suspended solids in Lemna System macrophyte wastewater treatment plant. Ecol. Eng. 58:262-265.

Dodson SI, Frey DG, 2001. Cladocera and other Branchiopoda, p. 850.914. In: J.H. Thorp, and A.P. Covich (eds.), Ecology and classification of North American freshwater invertebrates. Academic Press, London.

Dong J, Lu JJ, Li GB, Song LR, 2013. Influences of a submerged macrophyte on colony formation and growth of a green alga. Aquat. Biol. 19:265-274.

Doksaeter A, Vijverberg J, 2001. The effects of food and temperature regimes on life-history responses to fish kairomones in Daphnia hyalina x galeata. Hydrobiologia 42:207-214.

Duke SO, 2011. Phytotchemical phytotoxins and hormesis - a commentary. Dose-Response 9:76-78.

Dutartre A, Haury J, Jigorel A, 1999. Succesion of Egeria densa in a drinking water reservoir in Morbihan (France). Hydrobiologia 415:243-247.

Dumont HJ, Negrea SV, 2002. Branchiopoda. Backhuys Publishers, Leiden: 398 pp.

Erhard D, Gross EM, 2006. Allelopathic activity of Elodea canadensis and Elodea nuttalli against epiphytes and phytoplankton. Aquat. Bot. 85:203-211.

Fernández R, Nandini S, Sarma SSS, Castellanos-Paez ME, 2014. Effects of cyanobacteria, fish kairomones, and the presence of ostracods on the demography of Simocephalus vetulus (Cladocera). Invertebr. Biol. 133:371-380.

Gama-Flores JL, Castellanos-Paez ME, Sarma SSS, Nandini S, 2007. Life table demography of Ceriodaphnia dubia (Cladocera) exposed to copper at different levels and periods. J. Environ. Biol. 28:691-696.

Gilbert JJ, 2009. Predator-specific inducible defenses in the rotifer Keratella tropica. Freshwater Biol. 54:1933-1946.

Gopal B, Goel U, 1993. Competition and allelopathy in aquatic plant communities. Bot. Rev. 59:155-210.

Gross EM, 2003. Allelopathy of aquatic autotrophs. Crit. Rev. Plant. Sci. 22:313-339.

Gutierrez MF, Paggi JC, 2014. Chemical repellency and adverse effects of free-floating macrophytes on the cladoceran $\mathrm{Ce}$ - 
riodaphnia dubia under two temperature levels. Limnology 15:37-45.

Hilt S, 2006. Allelopathic inhibition of epiphytes by submerged macrophytes. Aquat. Bot. 85:252-256.

Hilt S, Gross EM, 2008. Can allelopathically active submerged macrophytes stabilize clear-water states in shallow lakes? Basic. Appl. Ecol. 9:422-432.

Iglesias C, Goyenola G, Mazzeo N, Meerhoff M, Rodó E, Jeppesen E, 2007. Horizontal dynamics of zooplankton in a subtropical lake Blanca (Uruguay) hosting multiple zooplankton predators and aquatic plant refuges. Hydrobiologia 584:179-189.

Körner S, Nicklish A, 2002. Allelopathic growth inhibition of selected phytoplankton species by submerged macrophytes. J. Phycol. 38:862-871.

Krebs CJ, 1985. Ecology; the experimental analysis of distribution and abundance. 3rd edition. Harper and Row, New York.

Lass S, Spaak P, 2003. Chemically induced anti-predator defences in plankton: a review. Hydrobiologia 491:221-239.

Lot A, Novelo A, 2004. [Iconografía y estudio de plantas acuáticas de la ciudad de México y sus alrededores].[Book in Spanish]. Instituto de Biología, Universidad Nacional Autónoma de México: 206 pp.

Lürling M, Geest GV, Scheffer M, 2006. Importance of nutrient competition and allelopathic effects in suppression of the green algae Scenedesmus obliquus by the macrophytes Chara, Elodea and Miriophyllum. Hydrobiologia 556:209-220.

Machacek J, 1991. Indirect effect of planktivorous fish on the growth and reproduction of Daphnia galeata. Hydrobiologia 225:193-197.

Malhotra YR, Langer S, 1991. Studies on some biological aspects of Simocephalus vetulus Schodler. J. Indian Inst. Sci. 71:523-530.

Mayeli SM, Nandini S, Sarma SSS, 2004. The efficacy of Scenedesmus morphology as a defense mechanism against grazing by selected species of rotifers and cladocerans. Aquat. Ecol. 38:515-524.

Meerhoff M, Fosalba C, Bruzzone C, Mazzeo N, Noordoven W, Jeppesen E, 2006. An experimental study of habitat choice by Daphnia; plants signal danger more than refuge in subtropical lakes. Freshwater Biol. 51:1320-1330.

Mulderij G, Mau B, van Donk E, Gross E, 2007. Allelopathy activity of Stratiotes aloides on phytoplankton towards identification of allelopathic substances. Hydrobiologia 584:89-100.

Muylaert K, Pérez-Martínez C, Sánchez-Castillo P, Lauridsen TL, Vanderstukken M, Declerck SAJ, van der Gucht K, CondePorcuna JM, Jeppesen E, De Meester L, Vyverman W, 2010. Influence of nutrients, submerged macrophytes and zooplankton grazing on phytoplankton biomass and diversity along a latitudinal gradient in Europe. Hydrobiologia 653:79-90.

Nakai S, Inoue Y, Hosomi M, Murakami A, 1999. Growth inhi- bition of blue-green algae by allelopathic effects of macrophytes. Water. Sci. Technol. 8:47-53.

Nandini S, Mayeli SM, Sarma SSS, 2004. Effect of stress on the life-table demography of Moina macrocopa. Hydrobiologia 526:245-254.

Nandini S, Sarma SSS, 2006. Ratio of neonate to adult size explains life history characteristics in cladoceran zooplankton. Acta Hydrochim. Hydrobiol. 34:474-479.

Orlova-Bienkowskaja MY, 2001. Cladocera: Anomopoda: Daphniidae, genus Simocephalus. Guides to the identification of the microinvertebrates of the continental waters of the world. Backhuys Publishers, Leiden: 130 pp.

Pennak RW, 1973. Some evidence for aquatic macrophytes as repellants for a limnetic species of Daphnia. Int. Rev. Ges. Hydrobiol. 58:569-576.

Santos MJ, Anderson LW, Ustin SL, 2011. Effects of invasive species on plant communities: an example using submersed aquatic plants at the regional scale. Biol. Invasions 13:443-457.

Sarma SSS, Nandini S, Gulati RD, 2005. Life history strategies of cladocerans: comparisons of tropical and temperate taxa. Hydrobiologia 542:315-333.

Sarma SSS, Nandini S, 2006. Review of recent ecotoxicological studies on cladocerans. J. Environ. Sci. Heal. B 41:1417-1430.

Scheffer M, 2004. Ecology of shallow lakes. Kluwer Academic Publishers, Dordrecht: 357 pp.

Scheffer M, Hosper SH, Meijer M-L, Moss B, Jeppesen E, 1993. Alternative equilibria in shallow lakes. Trends. Ecol. Evol. 8:255-270.

Sokal RR, Rohlf FL, 2000. Biometry. W.H. Freeman \& Co., New York.

Van Donk E, van de Bund WJ, 2002. Impact of submerged macrophytes including charophytes on phyto- and zooplankton communities: allelopathy versus other mechanisms. Aquat. Bot. 72:261-274.

Vanderstukken M, Mazzeo N, van Colen W, Declerck SAJ, Muylaert K, 2011. Biological control of phytoplankton by the subtropical submerged macrophytes Egeria densa and Potamogeton illinoensis: a mesocosm study. Freshwater Biol. 56:1837-1849.

Vanderstukken M, Declerck SAJ, Decaestecker E, Muylaert K, 2014. Long-term allelopathic control of phytoplankton by the submerged macrophyte Elodea nuttallii. Freshwater Biol. 59:930-941.

Weber CI, 1993. Methods for measuring the acute toxicity of effluents and receiving waters to freshwater and marine organisms. Document no. EPA/600/4-90/027F. U.S. Environmental Protection Agency, Cincinnati, OH, USA.

Wojtal A, Frankiewicz P, Izydorczyk K, Zalewski M, 2003. Horizontal migration of zooplankton in a littoral zone of the lowland Sulejow reservoir (central Poland). Hydrobiologia 506-509:339-346. 